THE CHACO DISPUTE

At the time of our last editorial ${ }^{1}$ several more or less distinct bodies had been attempting to stem the tide of war in the Chaco Boreal. The Council of the League of Nations had, under Article 4, been admonishing the belligerents as to their obligations but was deferring to the action of American mediators then actively engaged in trying to bring about an armistice and arbitration. Neither of the parties had brought the dispute before the League under the Covenant, although each had protested from time to time to the Council concerning certain "acts of aggression" while professing a desire for peace. The nineteen American nations had also made representations and issued their famous declaration of August 3, 1932. The four neighboring countries, Argentina, Brazil, Chile and Peru, had offered their good offices and conciliatory efforts to the belligerents in conjunction with the Commission of Neutrals. The Commission of Neutrals (United States, Uruguay, Colombia, Cuba and Mexico) was at the time continuing its efforts toward peace. In identic notes to the parties (September 22), it said: "That one country should continue the struggle when the other desires to put an end to hostilities will mean that it is using force as an instrument of its national policies . . . which is absolutely contrary to the declaration of the American nations of the $3 \mathrm{~d}$ of August last, a declaration which was accepted by Paraguay and Bolivia." The commission appealed to the combatants to accept a nonconditional termination of hostilities and the immediate initiation of negotiations for a settlement by arbitration without reservations. If accepted, the commission would send a delegation to the Chaco to report any violation of the agreement, declare the violator to be the aggressor, and suggest that the American nations sever diplomatic and consular relations with it. ${ }^{2}$

On the next day (September 23) the Council of the League of Nations discussed the Chaco dispute on the basis that the Covenant was the only treaty binding both parties to settle the dispute without recourse to arms. The Council decided to ask the American Republics for information and to appoint a Committee of Three to study and follow the matter closely. From then on the Council took an increasingly active interest in the dispute. At periodic sessions it discussed the dispute and impressed the representatives of Bolivia and Paraguay at the Council table with the Council's desire for peace. The Council emphasized the desirability of an immediate truce and the separation of the armies in the field under the supervision of a neutral commission on the spot.

As none of its earlier proposals had been accepted by either party, the Washington commission, on December 15, 1932, telegraphed the Council the details of its last proposal, namely, an agreement whereby the belligerents were to withdraw their forces to stated lines to be verified by a military commission, reduce their forces to peace-time strength, and police the Chaco

See this Journal, October, 1932, Vol. 26, page 796.

2 Note of Commission of Neutrals to Argentina, Nov. 4, 1932. 
separately. The legal rights or positions of the parties were not to be affected in any way. Fifteen days after ratification, negotiations for arbitration were to begin. If they failed within four months to agree on the area to be arbitrated, this question was to be submitted to experts named by three geographical societies, whose decision on the area should be final; one month thereafter, the arbitral tribunal was to determine the boundary within this area. In case of failure to agree on the tribunal, the Permanent Court was to take jurisdiction. The Commission of Neutrals, the Council, as well as the individual governments represented on the Council, all brought pressure to bear on the belligerents to accept this proposal. It appears that the League's new broadcasting station was first used for this purpose. The proposal was also approved by the other American republics.

The replies of the belligerents being unacceptable, the commission advised the Council, December 21, that it had now asked the A.B.C.P. countries what steps they would suggest to prevent bloodshed, adding the hint that the commission believed that American nations could preserve peace in this hemisphere. The parties also indicated to the Council that they preferred to have any action by it postponed. This view was adopted at the Council's meeting of February 3, 1933. The chairman of the Committee of Three, Najero of Mexico, said, "I can not help thinking that if there were sufficient good will and if both parties were ready to accept an impartial decision, the dispute could be settled without loss of life."

Meanwhile, the A.B.C.P. countries were in touch with the belligerents and busy formulating a new proposal (called the Act of Mendoza) which, with the approval of the Washington commission, was finally presented on February 24. This plan provided: (1) all Chaco questions to be arbitrated, any difference in determining the zone or submitting any particular point to be referred to the Hague Court for an advisory opinion; (2) hostilities to be declared at an end; (3) Bolivia to withdraw to Ballivian and Robore, and Paraguay to the Paraguay River; (4) effectives to be reduced. Both countries raised objections. Upon urgent appeals Paraguay withdrew hers, but Bolivia, resenting such pressure, refused to do so. She desired to lay down certain restricting principles as to arbitration, to include the zone of the Hayes Award, to bound the disputed area by the Paraguay River, Pilcomayo River, North Latitude $21^{\circ}$ and West Longitude $59^{\circ} 55^{\prime}$, and to make the presidents of the Supreme Courts of all the American nations the arbitrators.

The dispute now took a different turn. Great Britain, seconded by France, suggested to the Council a study of preventing the export of arms to Paraguay and Bolivia under Article 11 of the Covenant, which resulted in putting the dispute on the agenda under that article instead of Article 4, as theretofore. Subsequently, on May 10, 1933, Paraguay formally declared war on Bolivia in order to prevent, as she advised the Council, the transit of arms and supplies through or by neighboring countries. Her idea was that the Pact of Paris, to which she was a party, outlawed "war" but not "force." 
Bolivia protested the declaration of war to the Council, urging the penalties of Article 16 for violating the Covenant. The Committee of Three, on May 11 , telegraphed Bolivia and Paraguay as to whether they would accept arbitration of all questions to be arbitrated as well as the substance of those questions. Neither belligerent accepted. The Council took time for further consideration. On May 20 the Committee of Three reported to the Council the failure of American mediation, and urged the earlier plan of sending a League commission to the spot (as suggested by Spain six months earlier)-(1) to negotiate a cessation of hostilities; (2) to obtain an agreement for submitting the dispute to arbitration; (3) to keep the Council informed, and at its request, to investigate any phase of the dispute. Led by the Spanish delegate, members intimated that the League's obligation to solve the conflict had been blocked because of other mediators in the field, including non-members of the League.

After considerable discussion and negotiation with the parties, during which they stated their different claims and positions, the Committee of Three finally reported to the Council, on July 3, that both parties agreed to the dispatch of the Chaco Commission, which would do the best it could on the spot to bring about a settlement of the dispute along the lines of the May 20 th report, although the parties widely disagreed as to methods and principles. As a compromise, it was also agreed that the committee should begin negotiations simultaneously at Geneva for suspension of hostilities and an agreement as to arbitration pending the arrival of the Chaco Commission. The Council adopted the report of the committee:

During the following weeks, while the Chaco Commission was being constituted, the belligerents made charges and counter-charges of military activities on the front inconsistent with the "moral armistice," which threatened to wreck the carrying out of the Council's plan. Paraguay withdrew its complete approval of the plan and declined to enter into the proposed negotiations, and Bolivia insisted that an arbitration agreement should be negotiated before the cessation of hostilities, otherwise she would reconsider the matter of the Chaco Commission. Meanwhile, the Council admonished purely defensive tactics in the field.

On July 26 both belligerents notified the Council that their governments had agreed to ask the neighboring countries to act as the mandatory of the Council, in place of the proposed commission, to suggest a formula which would establish and guarantee a just and lasting peace. In the circumstances, the Council adopted the suggestion and invited (August 3 ) the A.B.C.P. countries to accept the mandate, while holding its action of July 3 in suspense and retaining full control of the dispute. After sounding out the belligerents on various propositions, the A.B.C.P. countries concluded that further efforts were useless and declined the invitation on October 1.

Thereupon the Council dispatched the Chaco Commission, composed of Spanish (Chairman), British, French, Italian and Mexican members, which 
arrived at Montevideo on November 3 and began its duties. Each belligerent had an assessor attached to the commission as the mouthpiece of its government. The labors of the commission continued until about March 20, when it sailed for Geneva and prepared its report of May 9, 1934. ${ }^{3}$ The report and draft peace treaty ${ }^{4}$ appeared to accentuate the tenseness between the belligerents, the differences in their views and the irreconcilable attitudes of the parties. A shield of defense shadows the failure to record a settlement or at least a suspension of hostilities. It is difficult to find in it any advance toward peace. It has been generously praised by members of the Council as a contribution to the controversy, but this may be due to other reasons than to any profound consideration which the report displays. The comments of Bolivia (May 16) were only mildly critical of the report, but those of Paraguay (July 9) were caustically pointed. She regarded the report as "one more factor of disturbance added to the many factors which are embittering the conflict." To quote from her conclusions:

The prejudiced point of view of the authors of the report is perfectly plain. The whole document reveals anxiety to criticise Paraguay and to excuse Bolivia. The impartiality of judgment and the accuracy of conception which might be expected from a commission of such high authority are not observed.

. . . It believed that the settlement of a question which it prejudged from the standpoint of one of the parties would solve all the differences that have today brought two devoted peoples face to face on the battlefield. It paid no attention to the political aspects of the problem. It failed to realize that only a very small part of the dispute could be dealt with by arbitration. Above all, it endeavored to turn its back upon a bloody reality. It was unwilling to realize the existence of a war and of an aggressor, and the consequences that that involved. . . .

In a word, whatever may be the judgment of the Council of the League on the report of the Chaco Commission, Paraguay is obliged to reject it, and to reject any future proposal that might be based on the conclusions of that report or on the draft treaties suggested by the Commission, for the practical and legal reasons hereinbefore set forth. The Commission's report has aroused in the people and Government of Paraguay a sense of terrible and unmerited injustice.

The report and other phases of the controversy were considered by the Council at seven meetings held in May and June last. The British representative, supported by other members, suggested again (May 17) proceeding with the arms embargo which had been suspended in anticipation of success by the Chaco Commission. They were desirous of showing that the League was not "an abstract institution uttering ineffectual oracles"; if the two countries

${ }^{3}$ See Supplement to this Journal, page 137.

4 This draft is similar in many respects to that proposed by the Washington commission, Dec. 16, 1932. 
would not accept the "equitable and honorable solution" of the Commission draft treaty, "they should be constrained by all means to stop the bloodshed."

While Paraguay was passive' to this proposal, Bolivia (May 18) vigorously objected to it on the ground of inequitable application due to differences in the geographical situations and transport facilities of the two belligerents. 6 She called attention to Article 22 of the Maritime Neutrality Convention of the Havana Conference of 1928, inserted, she said, at Bolivia's request with the approval of the United States, in regard to the transit of war materials to a land-locked country. ${ }^{7}$ Nevertheless, the Council proceeded to adopt (May 19) a resolution calling on the belligerents to re-examine the solution (draft treaty of Feb. 22) proposed by the commission, and directing the Committee of Three to consult the powers as to prohibiting the export and transit of war material.

At the May 31st meeting these matters were on the agenda. As to the draft treaty, Bolivia reserved on the exclusion of the Hayes zone from arbitration, while Paraguay maintained her earlier objections. As to the embargo on war material, Paraguay raised no objection, while Bolivia made an impassioned appeal:

No, gentlemen, you cannot destroy my country, for that is what you will be doing if you pronounce an embargo without first making a distinction. I warn you against it with all the force at my command. That force I draw from the anguish of a mutilated country, which has for fifty years been overwhelmed by fate and which exhibits, along with its loyalty to the Covenant, the sad origin of its wounds. Are you going to make use of those wounds against my country?

As the Committee of Three had not completed its consultation, action was postponed under reservations by Bolivia, but subsequently (June 14), it reported that none of the 35 governments ${ }^{8}$ heard from objected in principle to the embargo; five, including the United States, ${ }^{9}$ had already acted; about sixteen had agreed to do so unconditionally, and the rest on condition that certain or all of the others do so. Upon receipt of this report, the Bolivian delegate (June 27) notified the League, "I can not disguise the astonishment this document has produced in my country," and requested a reconsideration of the proposal.

At the same meeting (May 31), Bolivia, apparently being pressed by the embargo resolution, called for the application of Article 15 of the Covenant

${ }^{5}$ Of Feb. 22, 1933. See Supplement to this JoUnNaL, page 189.

- Compare the arguments made in the note of the United States to Austria-Hungary of August, 1915, this Jodrnal, Spl. Supp., Vol. 9 (1915), p. 166.

7 Article 22, paragraph 2, reads as follows:

"Transit shall be permitted when, in the event of a war between two American nations, one of the belligerents is a mediterranean country, having no other means of supplying itself, provided the vital interests of the country through which transit is requested do not suffer by the granting thereof." (This JournaL, Supp., Vol. 22 [1928], p. 156.)

8 Japan declined to take part in the plan.

- Joint Resolution and Proclamation of May 28, 1934. At that time Bolivia had in the United States partly completed contracts for war material totalling about $\$ 3,600,000$. 
to the dispute. The Council held (June 1) that Article 15 should be applied, that the Chaco Commission had already furnished the investigation required, and that the parties should present the statements of their cases as promptly as possible. Concurrently, it ruled (June 7), in agreement with the parties, that the conciliation procedure under Article 11 should continue. This was followed (June 9 ) by Bolivia's formal request that the Council lay the dispute before the Assembly under Article 15. Paraguay (June 11) made reservations to this request on the ground that Article 15 did not apply to a state of war in progress. Nevertheless the Council (September 7) resolved to refer the dispute to the Assembly while continuing its duties under Article $11 .^{10}$ On going to press, the controversy still rests in the Assembly."

One of the great difficulties in settling the dispute is that the Chaco has now become a political question between the two countries. It is no longer a purely legal question as to the title to the Chaco district, but also a question of the supremacy in this district of two neighboring countries who claim it as essential to their national life. A realization of this point of view explains the intensity of the controversy and the refusal of the disputants to yield on points which they deem vital. Paraguay insists on the suspension of hostilities, not a mere armistice, together with evacuation, demobilization and disarmament as guarantees of security, before a negotiation of a settlement of the substantive question by arbitration or other means. Bolivia, on the other hand, demands the negotiation of a settlement first as the best guarantee of peace and security, the suspension of hostilities and guarantees being matters for secondary consideration. There are also wide differences of view in respect of details of these main questions. And all the peace machinery in the world has so far failed to piece together a formula of reconciliation and settlement appropriate to the sensibilities and national interests involved.

L. H. Woolsey

\section{THE LOCAL REMEDY RULE}

During the war thirteen ships owned by Finnish shipowners were requisitioned in English ports to carry cargoes in the Allied cause. Most of the ships appear to have been used to carry British cargoes to France. In 1920, the Finnish Government, on behalf of the owners, made claim upon the British Government for compensation for the vessels taken. The British Government replied that the ships had been seized not by Great Britain but by a Russian committee, for whom British officials were merely agents for the physical seizure. They added that if there was a claim it could be made under the Indemnity Act of 1920 before the Admiralty Transport Arbitra-

${ }^{10}$ Meanwhile, according to the press, Argentina suggested to the United States and Brazil that they attempt mediation. This was apparently undertaken during the summer but came to no result. The documents of this mediation are not yet available.

11 The official reports of meetings of the Council and Assembly in September are not available on going to press. 